UDC 576.858

\title{
EXPERIMENTAL INFECTION OF BROWN TROUT (SALMO TRUTTA), ZEBRAFISH (DANIO RERIO), AND SWAN MUSSEL (ANODONTA CYGNEA) WITH INFECTIOUS PANCREATIC NECROSIS VIRUS (IPNV)
}

\author{
Yu. P. Rud ${ }^{1, *}$, M. I. Maistrenko ${ }^{2}$, O. V. Zaloilo ${ }^{1}$, G. A. Liubchenko ${ }^{2}$, \\ L. P. Buchatskiy ${ }^{2}$, I. I. Hrytsyniak ${ }^{1}$ \\ ${ }^{1}$ Institute of Fisheries of NAAS, \\ 135, Obukhivska Str, Kyiv, Ukraine, 03164 \\ ${ }^{2}$ Institute of Biology and Medicine of Taras Shevchenko National University of Kyiv, \\ 2, Acad. Hlushkova prosp., Kyiv, Ukraine, 02000 \\ E-mail:rudziknew@ukr.net*,maistrenko.mia@gmail.com,ozaloilo@yahoo.com, \\ gannalb@yahoo.com,iridolpb@gmail.com,info.iforgua@gmail.com
}

Received March 06, 2020 / Received July 13, 2020 / Accepted November 20, 2020

\begin{abstract}
Aim. Although more than 80 fish species and some invertebrate aquatic organisms are known to be susceptible to infectious pancreatic necrosis virus (IPNV) and aquatic birnaviruses, relatively little is known about its ability to infect brown trout (Salmo trutta), zebrafish (Danio rerio), and a mollusk, swan mussel (Anodonta cygnea). Therefore, the aim was to study in more detail the effects of IPNV on the said organisms. The information on the virulence of birnaviruses for aquatic organisms is important for better understanding of their transmission and for the identification of susceptible or transient (symptomless) hosts. Methods. Cell culture method, using RTG-2 cells, was used for in vitro cultivation of IPNV as well as virus titer assessment. The supernatants from infected RTG-2 cells were used for artificial inoculation to obtain experimental infection of the fish and mollusk. Fish and mollusk behaviour and mortality were monitored daily. The infectious titer of the virus in experimental animals was assessed by cell culture assay and reverse transcription PCR (RT-PCR). Results. This paper presents the results of IPNV experimental infection of brown trout (Salmo trutta), zebrafish (Danio rerio), and an aquatic invertebrate mollusk - swan mussel (Anodonta cygnea). The mortality of brown trout and zebrafish was 76.6 and $40 \%$ respectively. Swan mussel was apparently resistant to the virus, but it apparently accumulated and maintained substantial levels (up to $10^{-10} \mathrm{ID}_{50} / \mathrm{ml}^{-1}$ ) of the virus for the duration of the experiment (35 days). The highest infectious titer was found in brown trout $\left(10^{6} \mathrm{ID}_{50} / \mathrm{ml}^{-1}\right)$. In zebrafish and swan mussels, it was up to $10^{4.5} \mathrm{ID}_{50} / \mathrm{ml}^{-1}$ and $10^{2} \mathrm{ID}_{50} / \mathrm{ml}^{-1}$ respectively. Conclusions. At the end of the experiments the IPNV titers were higher than the initial viral doses in brown trout and zebrafish, indicating virus reproduction. In diseasesd fish the blackening, whirling and anorexia were observed. It was shown that swan mussel accumulates and maintains virus for at least 35 days under experimental conditions and that it may act as symptomless vector of IPNV.
\end{abstract}

Key words: IPNV, vectors, infectious titer, RT-PCR.

DOI: https://doi.org/10.15407/agrisp7.03.031

\section{INTRODUCTION}

Birnaviruses are the most common pathogens of aquatic animals. They were isolated from a wide variety of marine and freshwater fish and marine invertebrate shellfish such as crayfish, clamps and blue mus-

(C) Yu. P. RUD, M. I. MAISTRENKO, O. V. ZALOILO, G. A. LIUBCHENKO, L. P. BUCHATSKIY, I. I. HRYTSYNIAK, 2020 sel, (Vestergaard-Jørgensen, Bregnballe 1969; Bovo et al, 1984; Lo et al, 1988; Mortensen et al, 1992; Zhe et al, 2008). The infectious pancreatic necrosis virus (IPNV) is a typical representative of the Aquabirnavirus genus, Birnaviridae family and it causes infectious pancreatic necrosis in salmonid fish with its typical features (Dixon et al, 2008; Woo, Bruno, 2011; Dopazo, 2020).

At present IPNV is known for its ability to infect over 60 species of fish and 15 species of freshwater and ma- 
rine aquatic invertebrates (Woo, Bruno, 2011; Dopazo, 2020). The aquabirna eel virus European (EVE), isolated from European eel (Anguilla anguilla) and causing eel nephritis, does not cause disease in rainbow trout (Onchorhynchus mykiss), but after experimental infection of the closely related Japanese eel, (A. japonica), it induced 50-75\% mortality (Sano et al, 1981). IPNV isolated from moribund fry of striped bass Morone saxatilis does not couse any clinical or histopathological signs of disease in fingerlings striped bass of different strains even under the effects of environmental stress (Wechsler et al, 1986). The pathogenicity of Paralichthys olivaceus birnavirus (POBV) is higher in smaller fish. In addition the fry and juvenile flounder have different susceptibility to POBV, (Zhe et al, 2008; Jung et al, 2008). Pakingking et al, 2004 also reported that MABV-infected olive flounder did not show any abnormality, even when extremely high concentrations of MABV were detected $\left(10^{8.3} \mathrm{TCID}_{50} / \mathrm{g}\right)$. IPNV isolated in scallops (Pecten maximus) did not show mortality or clear pathological changes during experimental infection (Mortensen et al, 1990; 1992). IPNV, isolated from rainbow trout, easily induces the disease in chinook salmon (Onchorhynchus tshawytscha) and Atlantic salmon (Salmo salar), which demonstrates apparent virus transmission between the related species (Tafalla et al, 2006; Holopainen et al, 2017).

Bioaccumulating organisms may increase the risk of infection on fish farms, serving as reservoirs for relevant fish disease agents, including IPNV. Molloy et al, 2013 demonstrated the ability of blue mussel (Mytilus edulis) to bioaccumulate and transmit IPNV to smolts of Atlantic salmon but replication in this organism could not be proved or disproved. There was a report on IPNV replication in organs (hepatopancreatic tissue and haemolymph) of freshwater crayfish (Astacus astacus), revealed by electronic microscopy (Halder, Ahne, 1988). Rud et al (2014) so demonstrated that the Ukrainian Sp strain of IPNV, "Karpaty" (Genogroup 5), induced $26 \%$ mortality of the Danube crayfish (Pontastacus leptodactylus) after experimental infection. As rainbow trout, freshwater crayfish, and mussels coexist in one ecosystem, it was proven that these aquatic invertebrates may be infected with IPNV or accumulate it, feeding on infected rainbow trout, and/or vice versa, provide for virus transmission to rainbow trout when fish is kept in reservoirs with IPNV-infected freshwater invertebrates (Halder, Ahne, 1988; Molloy et al, 2013; Rud et al, 2014).

IPNV is an economically relevant infectious agent for trout farms in Ukraine, as it accounts for a roughly
$50 \%$ mortality of rainbow trout fry (Matvienko et al, 2014). The virus was isolated from rainbow trout fry on the farms of Western Ukraine (Rud et al, 2015). It was subsequently identified on many farms and in natural trout populations of Ukraine (Rud et al, 2013). Contrary to many other viruses, IPNV can be transmitted vertically via fertilized eggs and is not eliminated by the treatment of those eggs with disinfecting solution. The risk of introduction of infected eggs from abroad into the farms is high, as within the last 10 years the fertilized eggs have been mostly imported, while producers have been reducing their own spawning schools (https://dpss.gov.ua/; https://customs.gov.ua/).

Swan mussel (Anodonta cygnea) is a common freshwater species in Eastern Europe (Beran, 2019), and the understanding of its role in the IPNV dynamics in natural ecosystems may be relevant for aquaculture. This species plays an important role in freshwater ecosystems as a natural filterer (Bolotov et al, 2020). Brown trout (Salmo trutta) is a target species for aquaculture within the framework of the State program of stocking water objects with fish (https://darg.gov.ua/; https:// zakon.rada.gov.ua/), so it is important to determine whether the local IPNV strain cause(s) high mortality. Zebrafish (Danio rerio) is a common experimental species of fish, thus, the data regarding the Ukrainian IPNV Sp strain virulence are useful though do not relate to the aquaculture directly.

Therefore, the aim of our study was to determine susceptibility and sensitivity of a less studied fish host (brown trout) and to determine the role of the swan mussel, which may be directly related to the accumulation and transmission of IPNV. The experimental infections of brown trout, zebrafish, and swan mussel were performed with the strain Sp IPNV "Karpaty", isolated in Ukraine (Rud et al, 2015).

\section{MATERIALS AND METHODS}

Virus and cell culture. Cell line RTG-2, obtained from female gonad of rainbow trout (Onchorhynchus mykiss) was used for in vitro cultivation of the strain of infectious pancreatic necrosis virus "Karpaty" (Rud et al, 2015). RTG-2 cells were cultivated in MEM medium (Invitrogen, Carlsbad, CA) with the addition of $10 \%$ of inactivated fetal bovine serum FBS Gold (PPA, Austria) and $0.2 \%$ gentamicin (PC Darnytsia, Ukraine). The cells were cultivated as monolayer in $25 \mathrm{~cm}^{2}$ plastic flasks at $20^{\circ} \mathrm{C}$ (Wolf, Quimby 1962). The infectious titer of the virus in the cell culture (the tissue culture infective dose or $\mathrm{TCID}_{50}$ ) was calculated by the method of Reed and Muench (Reed, Muench, 1938). 
Experimental infection. The experimental infection was obtained using brown trout at the age of $0+$ with the weight of 10-15 g, mature zebrafish ( $4 \mathrm{~cm}$ of body length) and swan mussel under 5 years. The supernatants of culture medium from the infected RTG-2 cells were used for inoculation. Prior to inoculation, the inoculum was filtered though a syringe filter with $0.45 \mu \mathrm{m}$ pore diameter (Sarstedt, Germany). To achieve the infectious titer of $10^{3} \mathrm{TCID}_{50} / \mathrm{ml}^{-1}, 10$-fold serial dilutions were prepared. Sterile, disposable insulin syringes were used for injections and injections/ inculations were applied in abdominal caviety of fish and incurrent siphon of the swan mussel. After the injection, the experimental animals were placed into 40liter aquaria. The control groups were inoculated with the supernatant of culture medium of non-infected RTG-2 cells. Each experimental group as well as the control group consisted of 10 animals. The destructive samples to confirm the presence of the virus in the organism and to determine its titer were taken every 7 days on days 7, 14, 21, 28 or 35 after the infection, using one experimental fish or mollusk. Each experiment was conducted in three repeats. The behaviour and mortality of the experimental animals were monitored daily. The experiment lasted for 35 days.

Determining the infectious titer of the virus. The infectious titer of IPNV in the experimental animals was determined in RTG-2 cells. It required preparing the homogenates of kidney and spleen from brown trout, all internal organs of zebrafish and gills of swan mussel with a 1:10 dilution using Hanks' solution according to the OIE Aquatic Manual (OIE, 2016) (200 mg of tissue). The homogenates were centrifuged at $3,000 \mathrm{rpm}$ for $15 \mathrm{~min}$. The supernatants were filtered using $0.45 \mu \mathrm{m}$ syringe filter and $500 \mu \mathrm{l}$ of each was used to inoculate RTG-2 cells. Prior to inoculation, cell monolayers were washed with the Hanks' solution, thereafter RTG-2 cells were incubated together with the filtrate at $20^{\circ} \mathrm{C}$ for $2 \mathrm{~h}$. Then the filtrate was drained, and $5 \mathrm{Ml}$ fresh culture medium was added. The infected and control cells were monitored daily for the presence of morphological changes and visualization of the complete cytopathic effect (CCE) using an inverted biological microscope (ZEISS, Germany).

Conventional reverse transcription (RT-) PCR was used to detect the virus. Total RNA was extracted both from the cell culture and the samples of infected animals, using RNA GenJetTM set (Thermo Scientific, USA) according to the manufacturer's instructions. cDNA was synthesized from RNA using cDNA Rever-
tAidTM Premium First Strand Kit with recombinant M-MuLV RT according to the manufacturer's instructions (Thermo Scientific, USA). PCR was conducted using the primers, specific for the VP2 gene of IPNV according to Williams et al, 1999 and Blake et al, 1995. The following primers were used:

WB1 5'-CCGCAACTTACTTGAGATCCATTATGC-3', WB2 5'-CGTCTGGTTCAGATTCCACCTGTAGTG-3', PrA1 5'-TGAGATCCATTATGCTTCCAGA-3', PrA2 5'-GACAGGATCATCTTGGCATAGT-3'.

The WB primers were used to identify the virus in the infected animals throughout the experiment, as they are specific for birnaviruses, including IPNV and highly sensitive generating a small fragment of $204 \mathrm{bp}$ (Williams et al, 1999). PrA primers flank almost the fullsize viral gene VP2, encoding the capsid protein (Blake et al, 1995). As PrA primers in our experiments were more sensitive, therefore they were used to determine virus concentrations in infected animals and RTG-2 cells. To convert values of PCR products to equivalent titers of IPNV in PCR samples, the viral RNA was simultaneously determined in 10-fold serial dilutions of the supernatants of the infected cell culture RTG-2 and in the samples of infected animals, as adapted from the method of Falsey et al, 2003.

The PEQ STAR 96X Universal Gradient 96 well thermocycler was used for PCR (Life Science Competence Center Erlangen VWR International $\mathrm{GmbH}$ ). The reaction mixture contained the following components: $12.5 \mu 1$ DreamTaqTM Green PCR Master Mix (2X) (Thermo Scientific), oligonucleotide primers (Metabion, Germany) $-1 \mu 1$ each $(20 \mathrm{pmol} / \mathrm{ml}), 2 \mu 1$ of cDNA and sterile deionized water with the total volume $25 \mu$, including $2 \mu 1$ sample cDNA. PCR also included positive (viral RNA), negative (all components without cDNA) and internal ( $\beta$-actin gene specific primers) controls. The amplification conditions were as follows: an initial denaturation at $94{ }^{\circ} \mathrm{C}(3 \mathrm{~min}), 35$ cycles of denaturation at $94{ }^{\circ} \mathrm{C}(30 \mathrm{sec})$, annealing of primers at $60{ }^{\circ} \mathrm{C}(30 \mathrm{sec})$, synthesis at $72{ }^{\circ} \mathrm{C}(1 \mathrm{~min})$ and a termination of synthesis at $72{ }^{\circ} \mathrm{C}(7 \mathrm{~min})$. PCR products were analyzed in $2 \%$ agarose gel in TAE buffer (40 mM TRIS-HCl, $20 \mathrm{mM}$ of acetic acid, $1 \mathrm{mM}$ EDTA and stained with ethidium bromide $(0.5 \mu \mathrm{g} / \mathrm{mL}))$.

\section{RESULTS}

The infected RTG-2 cells were monitored visually every $24 \mathrm{~h}$, using an inverted microscope (ZEISS, Germany) at $100 \times$ magnification. On the third day after inoculation, the destruction of the cell monolayer and 

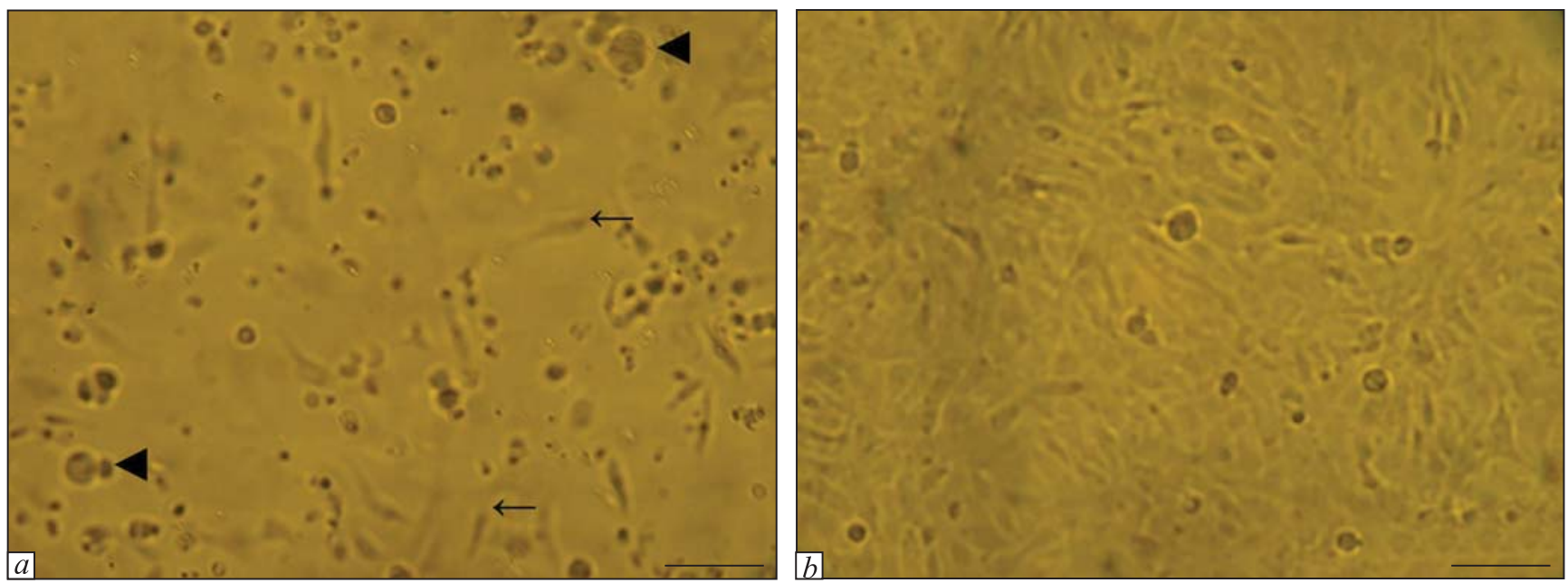

Fig. 1. The cytopathic effect of IPNV in the culture of RTG-2 cells on day 7 after inoculation $(a)$, as compared to the control culture $(b) . \varangle$ - large round cells; $\leftarrow$ several attached groups of cells (unstained cells, magnification $\times 100$, scale $\operatorname{bar}=100 \mu \mathrm{m})$

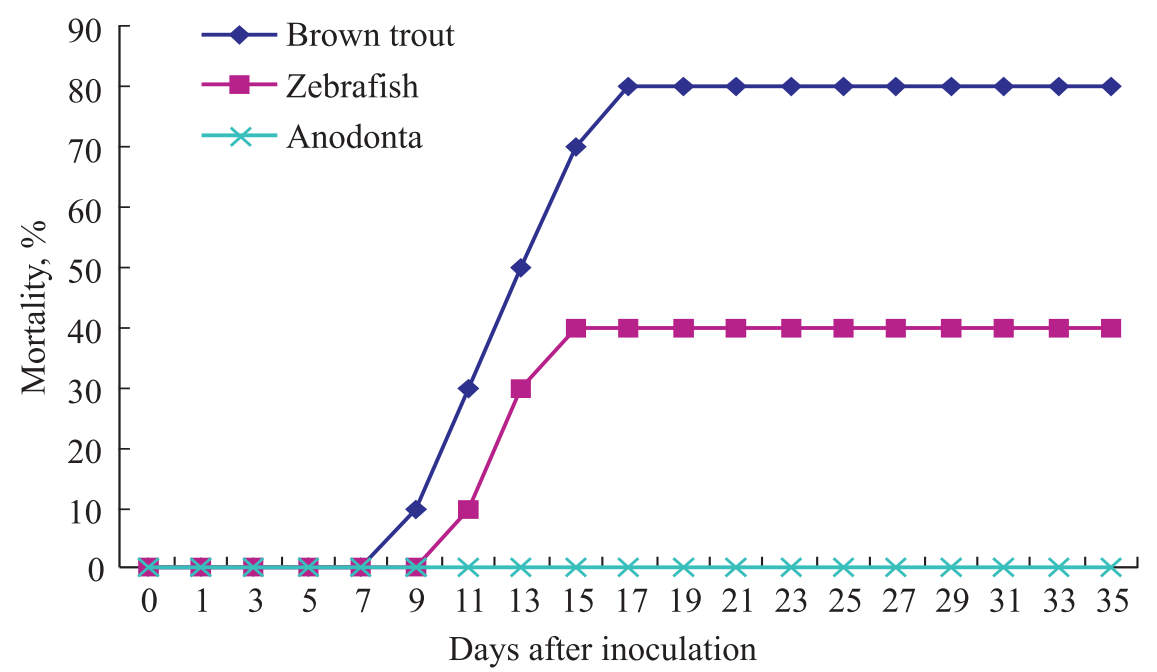

Fig. 2. The cumulative mortality for brown trout, zebrafish and swan mussel (10 specimen each per species), inoculated with a $10^{3} \mathrm{TCID}_{50} / \mathrm{ml}^{-1}$ dose of IPNV. None of the animals died in control groups

such morphological changes as cytoplasmic vacuolization and cell rounding were observed. A typical cytopathic effect of the virus on RTG-2 cell culture was observed on day 5 after inoculation. Most cells were detached from the bottom of the culture flasks and floating within the medium. Only several groups of cells, attached to the flask surface, remained instead of the total monolayer (Fig. 1, $a, b$ ). CCE of RTG-2 cells was observed on day 7 after inoculation. The infectious titer of IPNV "Karpaty" in RTG-2 cells was 10.9-7.4 $\mathrm{TCID}_{50} / \mathrm{ml}$.

Swan mussels were found to be able to accumulate and maintain substantial levels of IPNV. During the experiment they moved, actively opening and filtering water in the aquarium, and visual observations did not determine any signs of the disease. At the end of the experiment, the infected swan mussels and the ones in the control group continued their movements, were active and did not manifest any signs of the disease.

IPNV pathogenicity was proven for brown trout at the age of $0+$ with the weight of 10-15 g and mature zebrafish ( $4 \mathrm{~cm}$ of body length). The onset of the active infection development was registered on days 5-12 after inoculation and the fish that died did so within 12-18 days after inoculation (Fig. 2). The mortality for brown trout was $76.6 \pm 6.6 \%$. The initial symptoms included rapid breathing and staying at the surface of the water. Such signs of the infection as body darkening, 
typical swimming in circles, and exophthalmos were also noted. The necrosis of liver, kidneys, and digestive tract was observed which resulted finally in the destruction of all the organs and tissues, as determined post mortem. The infected zebrafish had hemorrhages and necrosis near to their pectoral fin. Prior to death, the infected zebrafish neither ate nor reacted to external stimuli and died within 10-15 days after inoculation. The mortality for zebrafish was $40.0 \pm$ $\pm 3.3 \%$ (Fig. 2).

RT-PCR demonstrated that all the experimentally infected animals were IPNV-positive. The presence of the virus was demonstrated on days $7,14,21,28$ or 35 after inoculation. It indicates that the virus may be accumulated and preserved in the organs of experimental animals and that it was multipied in the two fish species also. To determine the infectious titer of IPNV, samples of spleen and kidney of trout, pool of internal organs of zebrafish and gills of swan mussle were taken from all the experimental animals every 7 days throughout the experiment. The titer of the virus was determined in supernatant of RTG-2 cells, after total RNA extraction, undiluted RNA and additionally a 10-fold serial dilution of RNA samples was tested in the RT-PCR. The ten-fold serial dilution of tissue homogenates of the experimental animals was practically equal to the virus titer in the cultured RTG-2 cells. High correlation $(r=0.84)$ was observed between the data, obtained using RT-PCR directly on diseased tissue samples and the virus titer in cell cultures after inoculation with tissue extracts of brown trout, zebrafish, and swan mussel. RT-PCR demonstrated a reliable correlation with the virus titer while measuring in cell culture.
The amount of the virus in the kidney and spleen of brown trout increased c. 1,000 times, reaching its maximum of $10^{6} \mathrm{ID}_{50} / \mathrm{ml}^{-1}$ on day 21 after inoculation which is in agreement with the clinical course of the disease and extensive death of fish (c. $77 \%$, Table). Zebrafish was found to be sensitive to the Ukrainian isolate of IPNV as well, as the infectious titer of the virus increased ten times up to $10^{4} \mathrm{ID}_{50} / \mathrm{ml}^{-1}$. This titer of the virus was observed on day 14 after inoculation, then the level of the virus decreased to $10^{2} \mathrm{ID}_{50} / \mathrm{ml}^{-1}$. At the end of the experiment, at 35 days, IPNV was still present in zebrafish which demonstrated virus persistence.

The infectious titer of IPNV decreased gradually for swan mussel which resulted in the impossibility to determine its titer by the cell culture method 21 days after inoculation. The highly sensitive RT-PCR, however, could detect the virus still up to 35 days after inoculation) (Fig. 3) We demonstrated with this sensitive method that IPNV persists at low levels for a longer period of time (at least 35 days) and may serve as source of the virus.

\section{DISCUSSION}

The infectious pancreatic necrosis virus causes considerable global economic loss in the breeding of salmonids, with an average mortality of $50 \%$ (Bandin, Dopazo, 2011). The incidents of the disease, caused by IPNV, take place even in the countries with developed salmon breeding industry, which may be related to the import of infected and/or contaminated fish and fertilized eggs (Murray, 2006; Ruane et al, 2009). In addition to infectious pancreatic necrosis, the researchers determined ten more diseases, caused by aquatic birna-

The infectious titer of IPNV in the spleen and kidney of brown trout, pool of organs in zebrafish, and swan mussel gills and total mortality after artificial inoculation with the virus titer of $103 \mathrm{TCID}_{50} / \mathrm{ml}^{-1}$ as determined in RTG-2 cells and RT-PCR

\begin{tabular}{|c|c|c|c|c|c|c|c|c|}
\hline \multirow{2}{*}{ Experimental animal } & \multirow{2}{*}{$\begin{array}{l}\text { Method } \\
\text { of detection }\end{array}$} & \multicolumn{6}{|c|}{$\begin{array}{c}\text { Infectious titer of the virus } \\
\left(\mathrm{TCID}_{50} / \mathrm{ml}^{-1}\right) / \text { day after inoculation }\end{array}$} & \multirow{2}{*}{$\begin{array}{l}\text { Total mortality, \% } \\
\text { (after } 35 \text { days) }\end{array}$} \\
\hline & & 0 & 7 & 14 & 21 & 28 & 35 & \\
\hline \multirow[t]{2}{*}{ Swan mussel (Anodonta cygnea) } & $\mathrm{CC}$ & $10^{3}$ & $10^{3}$ & $10^{2}$ & $\mathrm{n} / \mathrm{d}$ & $\mathrm{n} / \mathrm{d}$ & $\mathrm{n} / \mathrm{d}$ & 0 \\
\hline & RT-PCR * & $10^{-4}$ & $10^{-3}$ & $10^{-3}$ & $10^{-2}$ & $10^{-1}$ & $10^{-1}$ & \\
\hline \multirow[t]{2}{*}{ Brown trout (Salmo trutta) } & $\mathrm{CC}$ & $10^{3}$ & $10^{5}$ & $10^{6}$ & $10^{6}$ & $10^{4}$ & $10^{3}$ & $76.6 \pm 6.6 \%$ \\
\hline & RT-PCR & $10^{-4}$ & $10^{-5}$ & $10^{-7}$ & $10^{-6}$ & $10^{-6}$ & $10^{-4}$ & \\
\hline \multirow[t]{2}{*}{ Zebrafish (Danio rerio) } & $\mathrm{CC}$ & $10^{3}$ & $10^{5}$ & $10^{4}$ & $10^{3}$ & $10^{2}$ & $10^{2}$ & $40.0 \pm 3.3 \%$ \\
\hline & RT-PCR & $10^{-4}$ & $10^{-4}$ & $10^{-4}$ & $10^{-4}$ & $10^{-3}$ & $10^{-2}$ & \\
\hline
\end{tabular}

Note. * viral titer estimated by RT-PCR as 10 -fold dilutions of extracted RNA; ** each experiment was repeated three times; $* * * \mathrm{n}=1 . \mathrm{n} / \mathrm{d}-$ not detectable; $\mathrm{CC}-$ cell culture. 
RUD et al.
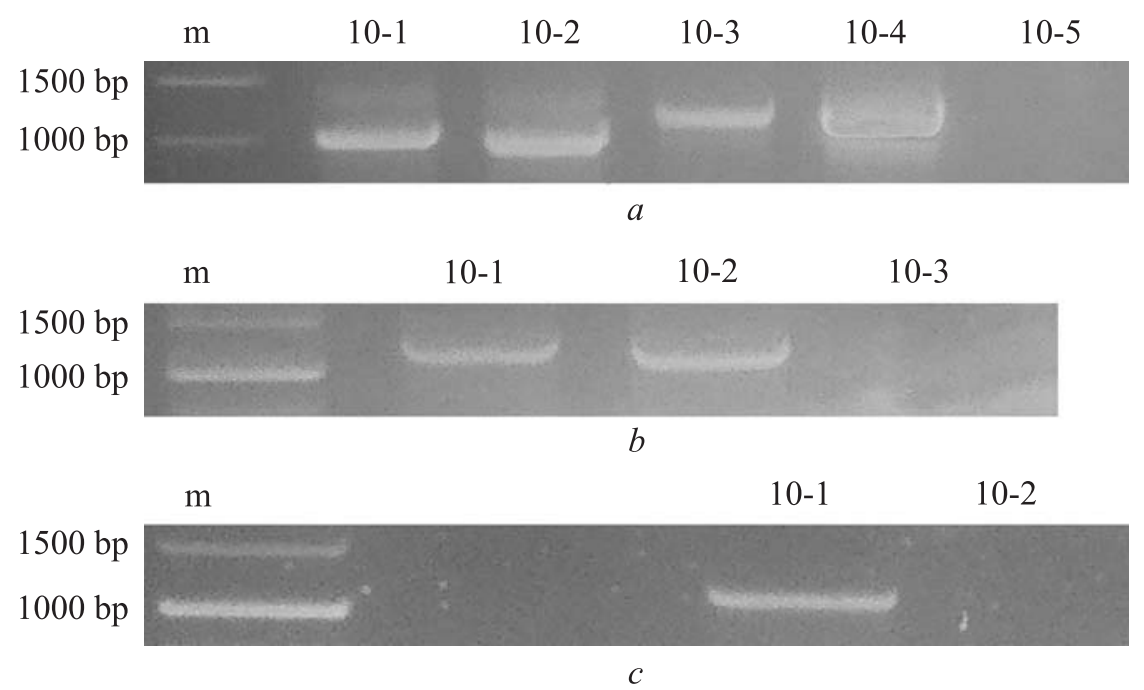

Fig. 3. Detection of IPNV in experimentaly infected brown trout (a), zebrafish (b), and swan mussel (c) at 35th day after infection by RT-PCR method using 10-fold dilutions of RNA and incorporating PrA primers (Blake et al, 1995)

viruses. Apart from IPNV, considerable damage to aquaculture is caused by marine birnavirus (MABV), yellowtail ascites virus (YAV) and Tasmanian aquabirnavirus (TAB), see Isshiki et al (2001). Therefore, to have a sustainable aquaculture, it is necessary to have constant monitoring of the populations of sensitive species and the condition of supplied water they are bred in. Imported fish and fertilized eggs should be visually examined, tested and when infected or contaminated destroyed. The results of our experiments demonstrated that IPNV may be maintained in the environment via its presence in a latent form or as contamination in shellfish invertebrates such as the swan mussel and crayfish (Rud et al, 2014). After eating/filtering infected fish, shellfish may maintain the virus and transmit it to other animals in their ecosystem, also via their faeces (Halder, Ahne, 1988; Rud et al, 2014; Molloy et al, 2013). In addition, IPNV is extremely stable in freshwater (up to one year under $4{ }^{\circ} \mathrm{C}$ ), salty and marine water, has the highest resistance in the environment among any other viruses of fish and can survive on equipment, in silage waste and in the gut of birds and mammals, so that it can also be transmitted via faeces (Toranzo, Hetrick 1982; Gregory et al, 2007).

As expected, brown trout, a natural host for IPNV (Dopazo, 2020), was very sensitive to the infection with IPNV in our experiments. The high mortality ( $77 \%$ ) of brown trout and the infectious titer of the virus demonstrated high virulence of IPNV strain "Karpaty" which was originally isolated from rainbow trout in 2013 from the Chernivtsi region (Rud et al, 2015). Most species of salmonids are sensitive to IPNV and brown trout is no exception. Our results demonstrated a potential risk of IPNV transmission between the populations of salmonids in the wild and in aquaculture farms of Ukraine. Virus can be transmitted through water exchange between infected farms and rivers, susceptible species and fish eggs even affect neighbouring countries (Wolf et al, 1963; Mutoloki et al, 2016).

Zebrafish were sensitive to IPNV, with a much lower $\left(10^{4} \mathrm{TCID}_{50}\right)$ infectious titer of the virus, compared to the brown trout $\left(10^{6} \mathrm{TCID}_{50}\right)$. The increased infectious titer as of the beginning of the experiment resulted in the generation of new virions of IPNV which demonstrated the sensitivity of zebrafish to the virus and the ability of the virus to replicate in the organism of this species. Zebrafish has been used over the years as a simple experimental model of studying virus reproduction in fish (Xu et al 2008; Sullivan, Kim, 2008). Our data are in good agreement with the results of American researchers (Byrne et al, 2008).

Several factors are likely to have been activated in the organism which started restricting virus replication as the level of IPNV decreased at the end of the experiment and the mortality of fish was not as high as that for brown trout. Further study on the expression of antiviral genes (vig-1/viperin or $\mathrm{Mx}$ ) has been planned to confirm our assumption, but the character of the infection, moderate virus titer, and low mortality may reflect defensive mechanisms proper.

Swan mussel was found to be probably resistant to the virus and no mortality was observed. Shellfish may play and was found to play a useful and decisive role in the systems of integrated multitrophic aquaculture (IMTA), using organic nutrients, related to filtration 
(Irisarri et al, 2015). Being bioaccumulating organisms, they can, however, increase the risk of infection with pathogens on farms, serving as reservoirs for relevant fish disease agents, including IPNV. The ability of blue mussel to bioaccumulate and transmit IPNV to smolts of Atlantic salmon was demonstrated. Although IPNV transmission took place from mussels to smolts with low frequency, the results demonstrated that such virus as IPNV may get accumulated in mussels and transmitted to sensitive species of fish (Molloy et al, 2013).

In our experiments the viral titer in swan mussels was gradually decreasing, but the virus was still present at the end of the experiment, on day 35 after inoculation. This fact demonstrated the potential of these animals as IPNV carriers since the IPNV concentration remained stable at a low titre of $10^{1}-10^{2} \mathrm{TCID}_{50} / \mathrm{ml}^{-1}$ throughout the experiment. After penetrating the organism, the virus may be eliminated by the mussel's defense mechanisms and its infectious titer indeed was reduced. Electron microscopic studies demonstrated the replication of IPNV in a freshwater crustacean crayfish, Astacus astacus (Halder, Ahne, 1988). The authors also suggested the vector function of crayfish, capable of transmitting and releasing the virus into the environment. As rainbow trout and freshwater crayfish are often kept together in one biotope, it was proven that crayfish may get infected by IPNV, while eating infected rainbow trout and, vice versa, transmit the virus to rainbow trout fry, when fish is kept in the same water with infected freshwater crayfish. It was also demonstrated that IPNV may be preserved in the organs of infected freshwater crayfish up to one year (Halder, Ahne, 1988).

The fibroblast-like cell line, derived from rainbow trout (Oncorhynchus mikyss) female gonad, RTG-2 is suitable for the accumulation of viruses, including mammal viruses and also the infectious pancreatic necrosis virus (Cutrin et al, 2009). As IPNV is a highly contagious virus, we observed considerable infectious titers RTG-2 (up to $10^{6} \mathrm{TCID}_{50} / \mathrm{ml}$ ) that can be compared with titers found by other researchers (Lorenzen et al, 1999; Matvienko et al, 2014). To determine the infectious titer of IPNV in brown trout, zebrafish, swan mussel, and the Danube crayfish, we studied the samples of tissues using the cell culture and RT-PCR. The latter following the method of LaPatra et al. 2000. RT-PCR was found to be more sensitive in detecting low virus concentrations. For instance, we failed to determine the virus in swan mussel on day 35 after inocu- lation, using the cell culture method, but the virus was still detectable by RT-PCR in 3 of 5 cases. However the results of the present study demonstrate that both cell culture and RT-PCR are reliable tests for the detection of low amounts of IPNV, as was shown by other researchers (Orpetveit et al, 2010).

The results of the present study about the virus, its carriers and new potential hosts/carriers may be helpful in finding new instruments for diagnostics and prevention of the infectious pancreatic necrosis of fish in Ukraine. To determine intracellular localization of the virus and to prove its replication in the organism of experimental animals, the electron microscopic study of ultra thin sections of relevant tissues will be conducted in the near future.

\section{CONCLUSIONS}

At the end of our artificial inoculation experiments IPNV titers in brown trout and zebrafish were higher $\left(10^{6} \mathrm{TCID}_{50} / \mathrm{ml}^{-1}\right.$ and $\left.10^{4} \mathrm{TCID}_{50} / \mathrm{ml}\right)$ than the initial viral doses, indicating virus reproduction.

Swan mussel is IPNV-resistant but is apparently accumulating virus and may serve as a vector and temporary reservoir for the virus.

Adherence to ethical principles. The studies were conducted in compliance with the standards of working with animals in accordance with the Order of conducting experiments involving animals in scientific institutions (the regulatory document of the Ministry of Education, Science, Youth, and Sport of Ukraine, the Order No. 249 dated March 01, 2012).

Conflict of interest. There is no conflict of interests between the authors, or the authors and other private individuals or legal entities.

Financing. This study was supported by the NAAS of Ukraine within the framework of the scientific technical task "To investigate molecular and biological properties and phylogenic characteristics of the agents of infectious diseases of fish" (0116U001219).

\section{Експериментальне інфікування струмкової форелі (Salmo trutta), даніо (Danio rerio), та беззубки (Anodonta cygnea) вірусом інфекційного панкреатичного некрозу (IPNV)}

Ю. П. Рудь ${ }^{1, *}$, М. І. Майстренко ${ }^{2}$, О. В. Залоїло ${ }^{1}$, Г. А. Любченко ${ }^{2}$, Л. П. Бучацький ${ }^{2}$, I. І. Грициняк ${ }^{1}$

${ }^{1}$ Інститут рибного господарства НААН, вул. Обухівська, 135, Київ, Україна, 03164

${ }^{2}$ Інститут біології та медицини Київського національного університету імені Тараса Шевченка, прос. Академіка Глушкова 2, Київ, Україна, 02000 
E-mail: rudziknew@ukr.net*,maistrenko.mia@gmail.com, ozaloilo@yahoo.com,gannalb@yahoo.com, iridolpb@gmail.com, info.iforgua@gmail.com

Мета. Оскільки більше 80 видів риб та безхребетних організмів чутливі до вірусу інфекційного панкреатичного некрозу (IPNV) та інших водних бірнавірусів, метою роботи було дослідити здатність вірусу інфікувати струмкову форель, даніо реріо та беззубку. Інформація про вірулентність бірнавірусів для гідробіонтів має особливе значення для кращого розуміння їх передачі та визначення чутливих хазяїв. Методи. Метод культури клітин використовували для культивування IPNV в умовах in vitro, а також для оцінки титру вірусу. Для експериментальної інфекції використовували супернатанти інфікованих клітин. Поведінку та смертність риб контролювали щодня. Інфекційний титр вірусу у піддослідних тварин визначали шляхом аналізу в культурі клітин та ПЛР зі зворотноью транскрипціїєю (ЗТ-ПЛР). Результати. У даній роботі представлені результати експериментального інфікування IPNV струмкової форелі, даніо та беззубки. Летальність у струмкової форелі становила $76,6 \%$, а у даніо - $40 \%$. Беззубка виявилась стійкою до вірусу. Найвищий інфекційний титр вірусу виявляли у форелі $\left(10^{6} \mathrm{ID}_{50} / \mathrm{M}^{-1}\right)$. Інфекційний титр у даніота беззубки становив $10^{4,5} \mathrm{ID}_{50} / \mathrm{MJ}^{-1} \mathrm{Ta} 10^{2} \mathrm{ID}_{50} / \mathrm{MJ}^{-1}$ відповідно. Висновки. Титри IPNV наприкінці експериментів були вищими, ніж початкові дози вірусу у струмкової форелі та даніо, що свідчить про розмноження вірусу. Було показано, що беззубка може накопичувати і підтримувати вірус протягом не менше 35 днів в експериментальних умовах і виступати як безсимптомний переносник IPNV.

Ключові слова: IPNV, експериментальне інфікування, вектори, інфекційний титр.

\section{REFERENCES}

Bandin I, Dopazo CP. (2011) Host range, host specificity and hypothesized host shift events among viruses of lower vertebrates. Vet. Res. 42:67. doi: 10.1186/1297-9716-42-67.

Beran L. (2019) Distribution and recent status of freshwater mussels of family Unionidae (Bivalvia) in the Czech Republic. Knowl. Manag. Aquat. Ecosyst. 420:45. doi: 10.1051/kmae $/ 2019038$.

Blake SL, Schill WB, McAllister PE et al. (1995) Detection and identification of aquatic birnaviruses by PCR assay. J. Clin. Microbiol. 33(4):835-839. PMID: 7790447, PMCID: PMC228051.

Bolotov IN, Kondakov AV, Konopleva ES et al. (2020). Integrative taxonomy, biogeography and conservation of freshwater mussels (Unionidae) in Russia. Sci. Rep. 10:3072. doi: 10.1038/s41598-020-59867-7.

Bovo G, Cescha G, Giogetti $G$ et al. (1984) Isolation of an IPN-like virus from adult kuruma shrimp (Penaeus japonicus). Bull. Eur. Assoc. Fish Pathol. 4(2):21-25.

Byrne N, Castric J, Lamour F et al. (2008) Study of the viral interference between infectious pancreatic necrosis virus (IPNV) and infectious haematopoietic necrosis virus (IHNV) in rainbow trout (Oncorhynchus mykiss). Fish Shellfish Immunol. 24:489-497. doi: 10.1016/j.fsi. 2007.08.010.

Cutrin JM, Olveira JG, Bandin I et al. (2009) Validation of real time RT-PCR applied to cell culture for diagnosis of any known genotype of viral haemorrhagic septicaemia virus. J. Virol. Methods. 162:155-162. doi: 10.1016/j. jviromet.2009.07.033.

Dixon PF, Ngoh G-H, Stone DM et al. (2008) Proposal for a fourth aquabirnavirus serogroup. ArchVirol. 153:19371941. doi: 10.1007/s00705-008-0192-9.

Dopazo CP. (2020) The Infectious Pancreatic Necrosis Virus (IPNV) and its virulence determinants: What is known and what should be known. Pathogens. 9:94. doi: 10.3390/pathogens 9020094 .

Falsey AR, Formica MA, Treanor JJ et al. (2003) Comparison of Quantitative Reverse Transcription-PCR to viral culture for assessment of Respiratory Syncytial Virus shedding. J. Clin. Microbiol. 41(9):4160-4165. doi: 10. 1128/JCM.41.9.4160-4165.2003.

Gregory A, Munro LA, Wallace IS et al. (2007) Detection of infectious pancreatic necrosis virus (IPNV) from the environment in the vicinity of IPNV-infected Atlantic salmon farms in Scotland. Fish Dis. 30:621-630. doi: 10.1111/j.1365-2761.2007.00844.x.

Halder M, Ahne W. (1988) Freshwater crayfish Astacus astacus - a vector for infectious pancreatic necrosis virus (IPNV). DisAquat Org. 4:205-209.

Holopainen R, Eriksson-Kallio AM, Gadd T. (2017) Molecular characterisation of infectious pancreatic necrosis viruses isolated from farmed fish in Finland. Arch. Virol. 162:3459-3471. doi: 10.1007/s00705-017-3525-8.

Irisarri J, Fernández-Reiriz MJ, Labarta U, Cranford PJ, Robinson SMC. (2015) Availability and utilization of waste fish feed by mussels Mytilus edulis in a commercial integrated multi-trophic aquaculture (IMTA) system: A multi-indicator assessment approach. Ecol. Indic. 48: 673-686. doi: 10.1016/j.ecolind.2014.09.030.

Isshiki T, Nagano T, Suzuki S. (2001) Infectivity of aquabirnavirus strains to various marine fish species. Dis. Aquat Org. 46:109-114. doi: 10.3354/dao046109.

Jung SJ, Kim SR, Joung IY, Kitamura S, Ceong HT, Oh MJ. (2008) Distribution of marine birnavirus in cultured olive flounder Paralichthys olivaceus in Korea. J. Microbiol. 46(3):265-273. doi: 10.1007/s12275-008-0004-7.

LaPatra SE, Barone L, Jones GR et al. (2000) Effects of Infectious Hematopoietic Necrosis Virus and Infectious Pancreatic Necrosis Virus Infection on Hematopoietic Precursors of the Zebrafish. Blood Cells Mol. Dis. 26:445-452. doi: 10.1006/bcmd.2000.0320.

Lo CF, Hong YW, Huang SYet al. (1988) The characteristics of the virus isolated from the gill Meterix lusoria. Fish Pathol. 23(3):147-154. doi: 10.3147/jsfp.23.147. 
Lorenzen E, Carstensen B, Olesen NJ. (1999) Inter-laboratory comparison of cell lines for susceptibility to three viruses: VHSV, IHNV and IPNV. Dis Aquat Organ. 37(2):81-88. doi: 10.3354/dao037081.

Matvienko NM, Rud YuP, Buchatskiy LP. (2014) Replication of Infectious Pancreatic Necrosis Virus in different cell lines and in rainbow trout (Oncorhynchus mykiss) fingerlings. Arch. Polish. Fish. 22:127-133. doi: 10.2478/ aopf-2014-0012.

Molloy SD, Pietrak MR, Bricknell I et al. (2013) Experimental transmission of Infectious Pancreatic Necrosis Virus from the Blue Mussel, Mytilus edulis, to cohabitating Atlantic Salmon (Salmo salar) smolts. Appl. Environ. Microbiol. 79(19):5882-5890. doi: 10.1128/AEM.01142-13.

Mortensen SH, Hjeltnes B, Rodseth O, Krogsrud J, Christie $K E$. (1990) Infectious pancreatic necrosis virus, serotype N1, isolated from Norwegian halibut (Hippoglossus hippoglossus), Turbot (Scopthalmus maximus), and scallops (Pecten maximus). Bull. Eur. Assoc. Fish Pathol. 10:42-44.

Mortensen SH, Bachere E, Gall GL. (1992) Persistence of infectious pancreatic necrosis virus (IPNV) in scallops Pecten maximus. Dis AquatOrgs, 12:221-227. doi: 10. 3354/dao012221.

Murray AG. (2006) A model of the emergence of infectious pancreatic necrosis virus in Scottish salmon farms 1996-2003. Ecol. Modell. 199:64-72. doi: 10.1016/j. ecolmodel.2006.06.010.

Mutoloki S, Jøssund TB, Ritchie G et al. (2016) Infectious pancreatic necrosis virus causing clinical and subclinical infections in Atlantic salmon have different genetic fingerprints. Front. Microbiol. 7:1393. doi: 10.3389/fmicb. 2016.01393.

OIE: Manual of Diagnostic Tests for Aquatic Animals, 7th Edition (2016) World organisation for animal health, 2016, Paris, FRANCE: http://www.oie.int.

Orpetveit I, Mikalsen AB, Sindre H, Evensen O, Dannevig BH, Midtlyng PJJ. (2010) Detection of infectious pancreatic necrosis virus in subclinically infected Atlantic salmon by virus isolation in cell culture or real-time reverse transcription polymerase chain reaction: influence of sample preservation and storage. Vet Diagn Invest. 22(6):886-895.

Pakingking R, Okinaka JrY, Mori KI, Arimoto M, Muroga $K$, Nakai T. (2004) In vivo and in vitro analysis of the resistance against viral haemorrhagic septicaemia virus in Japanese flounder (Paralichthys olivaceous) precedingly infected with aquabirnavirus. Fish Shellfish Immun. 17, 1-11. doi: 10.1016/j.fsi.2003.10.005.

Reed LJ Muench H. (1938) A simple method of estimating fifty percent endpoints. Am. J. Hyg. 27:493-497.

Ruane NM, McCarthy LJ, Swords D et al. (2009) Molecular differentiation of infectious pancreatic necrosis virus isolates from farmed and wild salmonids in Ireland. J. Fish. Dis. 32:979-987. doi: 10.1111/j.1365-2761.2009.01080.x.

Rud Yu, Maistrenko M, Buchatsky L. (2013) Isolation of Infectious pancreatic necrosis virus from wild-life rainbow trout Onchorhynchus mykis in Western Ukraine. Bull. T. Shevchenko Nat. Univ. Kyiv. Series: Biology, 65:63-65.

Rud YuP, Maistrenko MI, Bezusiy OL et al. (2014) Experimental infection of freshwater crayfish (Pontastacus leptodactylus) with Infectious Pancreatic Necrosis Virus. Bull. Prob. Biol. Med. 4(113):70-74.

Rud YuP, Maistrenko MI, Buchatskiy LP. (2015) Characterization of an infectious pancreatic necrosis virus from rainbow trout fry (Onhorhynchus mykiss) in West Ukraine. Virol. Sin. 30(3):231-233. doi: 10.1007/s12250014-3513-z.

Sano T, Okamoto N, Nishimura T. (1981) A new viral epizootics of Anguilla japonica, Temmink and Schlegel. J. Fish. Dis. 4:127-139. doi: 10.1111/j.1365-2761.1981. tb01117.x.

Sullivan K, Kim CH. (2008) Zebrafish as a model for infectious disease and immune function. Fish Shellfish. Immun. 25:341-350. doi: 10.1016/j.fsi.2008.05.005.

Toranzo AE, Hetrick FM (1982) Comparative stability of two salmonid viruses and poliovirus in fresh, estuarine, and marine waters. J. Fish. Dis. 5:223-231. doi: 10.1111/ j.1365-2761.1982.tb00477.x.

Tafalla C, Rodriguez Saint-Jean S, Pérez-Prieto S. (2006) Immunological consequences of the coinfection of brown trout (Salmo trutta) with infectious hematopoietic necrosis virus (IHNV) and infectious pancreatic necrosis virus (IPNV). Aquaculture, 256:15-22. doi: 10.1016/j. aquaculture.2006.01.027.

Vestergaard-Jørgensen PE, Bregnballe F. (1969) Infectious pancreatic necrosis in rainbow trout (Salmo gairdneri) in Denmark. Nord. Vet. Med. 21:142-148.

Wechsler SJ, Schultz CL, McAllister PE et al. (1986) Infectious pancreatic necrosis virus in striped bass, Morone saxatilis: experimental infection of fry and fingerlings. Dis Aquat Org. 1:203-208.

Williams K, Blake S, Sweeney A et al. (1999) Multiplex reverse transcriptase PCR assay for simultaneous detection of three fish viruses. J. Clin. Microbiol. 37(12):4139-4141. PMID: 10565946, PMCID: PMC85902.

Wolf K, Quimby MC. (1962) Established eurythermic line of fish cells in vitro. Science. 135:1065-1066.

Wolf K, Quimby MC, Bradford AD. (1963) Egg-associated transmission of IPN virus of trouts. Virology. 21(3): 317 321. doi: 10.1016/0042-6822(63)90192-2.

Woo PTK, Bruno DW. (2011) Fish Diseases and Disorders. vol. 3: Viral, Bacterial and Fungal Infections. CABI. 2011:944 p.

Xu X, Zhang L, Weng S et al. (2008) A zebrafish (Danio rerio) model of infectious spleen and kidney necrosis virus (ISKNV) infection. Virology, 376:1-12. doi: 10.1016/j. virol.2007.12.026.

Zhao Z, Ke F, Li Z et al. (2008) Isolation, characterization, and genome sequence of a birnavirus strain from flounder Paralichthys olivaceus in China. Arch. Virol .153:11431148. doi: 10.1007/s00705-008-0075-0. 